W niniejszym dziale zamieszczamy wybrane streszczenia rozpraw doktorskich dotyczących chorób nowotworowych, obronionych przed Radą Naukową Centrum Onkologii — Instytutu im. Marii Skłodowskiej-Curie oraz w innych ośrodkach naukowych w kraju. Zachęcamy Doktorantów do kontaktu z Redakcją Nowotworów i nadsyłanie propozycji na adres: redakcja@coi.waw.pl.

Inną możliwością publikacji doktoratu, do której również zachęcamy, jest przedstawienie go w obszerniejszej formie — w postaci klasycznej pracy oryginalnej.

\title{
Biopsja węzła wartowniczego w raku jelita grubego — wskazania i technika, czynniki warunkujące skuteczność, wpływ mikroprzerzutów na przeżycia odległe
}

\author{
Piotr Nowaczyk
}

\author{
Promotor: dr hab. n. med. Dawid Murawa \\ Recenzenci: prof. dr hab. n. med. Wojciech Zegarski, prof. dr hab. n. med. Zbigniew Krasiński \\ Data obrony: 3 grudnia 2014 rok
}

W przypadku raka jelita grubego najistotniejszym czynnikiem prognostycznym, pogarszającym 5-letnie przeżycia ○ 40\%-50\%, jest stwierdzenie przerzutów w węzłach chłonnych. Zastosowanie w tej grupie pacjentów chemioterapii uzupełniającej poprawia przeżycia. Z drugiej strony aż do 30\% chorych z rakiem jelita grubego w stadium I i II umrze w ciągu 5 lat z powodu wznowy miejscowej lub rozsiewu choroby. Najistotniejsza wydaje się więc możliwość poprawy diagnostyki układu chłonnego. Już samo seryjne skrojenie materiału umożliwia stwierdzenie mikroprzerzutów w nawet $20 \%$ węzłów negatywnych w technice standardowej. Dodatkowe, dokładniejsze techniki, takie jak barwienia immunohistochemiczne czy RT-PCR, wymagają dużego nakładu czasowego i finansowego, a ich wykonanie na całym materiale węzłowym usuniętym w trakcie zabiegu jest trudne i nieopłacalne. Zasadnym wydaje się poddanie dokładniejszemu badaniu jedynie wyselekcjonowanej grupy węzłów, o największym ryzyku posiadania komórek przerzutowych, czyli węzłów wartowniczych. Aktualnie biopsja węzła wartowniczego $w$ tej grupie chorych ma na celu doprecyzowanie potencjalnie zaniżonego zaawansowania ocenionego w zwykłych barwieniach węzłów chłonnych poprzez odnalezienie w immunohistochemii ognisk komórek nowotworowych niemożliwych do stwierdzenia w badaniu hematoksyliną i eozyną. Standardem leczenia pozostaje resekcja en-bloc guza z marginesem tkanek zdrowych i spływem chłonnym zawartym w krezce.

Celem pracy była ocena wyników biopsji węzła wartowniczego u chorych na raka jelita grubego, czynników wpływających na jej skuteczność oraz wpływu mikroprzerzutów w węzłach wartowniczych na przeżycia w kontekście wykorzystania tej procedury jako dodatkowego elementu w korelacji z innymi czynnikami ryzyka, decydującego o kwalifikacji chorego z grupy pierwotnie pN0 do leczenia adiuwantowego.

Analizowano 132 biopsje węzła wartowniczego wykonane w przypadku raka okrężnicy u chorych operowanych w latach 2005-2012 w Oddziale Chirurgii Onkologicznej i Ogólnej I Wielkopolskiego Centrum Onkologii. Do procedury — po uzyskaniu zgody - kwalifikowano chorych powyżej 18 r.ż. z potwierdzonym resekcyjnym rakiem okrężnicy, nieoperowanych wcześniej w zakresie okrężnicy. Wyłączono pacjentów ze śródoperacyjnie stwierdzonymi podejrzanymi węzłami, guzami T4, przerzutami odległymi, guzami synchronicznymi, operowanych ze wskazań nagłych. Łącznie 96 pacjentów (72,7\%) zakwalifikowanych do biopsji węzła wartowniczego było w stadium I i ll choroby. Zabiegi wykonywano metodą otwartą, podając podsurowicówkowo z 4 wkłuć wokół guza niebieski barwnik Patent Blue. Po 5-10 minutach identyfikowano węzeł wartowniczy, zaznaczając go szwem/klipsem lub pobierając jako odrębny preparat. W następnym etapie kontynuowano klasyczną resekcję en-bloc guza z układem chłonnym krezki. Węzeł wartowniczy, oprócz standardowej analizy hematoksyliną i eozyną, 
poddany został barwieniu immunohistochemicznemu — przeciwciała przeciwko ludzkim cytokeratynom: CK20, CAM 5.2, CKAE1/AE3 oraz CKMNF116. Jako dodatni węzeł wartowniczy klasyfikowano węzeł z makroprzerzutem lub węzeł, w którym w immunohistochemii stwierdzono mikroprzerzuty. Dla oceny jakości procedury wyliczono stopień detekcji, czułość, zgodność, wyniki fałszywie negatywne oraz negatywną wartość predykcyjną. Określono również nietypowy spływ chłonny oraz upstaging uzyskany dzięki immunohistochemii. Wyniki zestawiono z wiekiem i płcią pacjentów, BMI (w kilku modyfikacjach), indeksem Rohera, beztłuszczową masą ciała, procentową zawartością tłuszczu w organizmie oraz stosunkami masy pacjenta do masy idealnej według wzorów Broca, Broca na masę idealną, Lorentza, Pottona, Devine’a, Robinsona, Millera, Hamwiego. Analizie poddano również śródoperacyjną lokalizację choroby, makroskopowy charakter nowotworu, maksymalny wymiar guza $w \mathrm{~cm}$, powierzchnię guza $w \mathrm{~cm}^{2}$, procentowe zajęcie okrężnego światła jelita, stopień zróżnicowania nowotworu, grubości nacieku ściany według TNM, stopień zaawansowania nowotworu według TNM, obecność makroprzerzutów w węzłach chłonnych oraz obecność nacieku torebki węzłów, nacieku tkanki okołowęzłowej i zatorów nowotworowych w naczyniach. Następnie dokonano analizy wpływu mikroprzerzutów na przeżycia w grupie 100 pacjentów z minimum 3-letnią obserwacją po zabiegu. Porównano przeżycia dla grup chorych ze względu na wyjściowe zaawansowanie choroby nowotworowej: grupy chorych bez przerzutów w węzłach, z mikroprzerzutami w węźle wartowniczym oraz z makroprzerzutami. Następnie wykonano analizę przeżyć, wyłączając — zgodnie z danymi na koniec okresu obserwacji —osobną grupę chorych z rozsiewem nowotworu. W analizie statystycznej wykorzystano test niezależności Chi-kwadrat, krzywe ROC oraz test wskaźnika struktury. Do analizy przeżyć wykorzystano estymację funkcji przeżycia metodą Kaplana-Meiera, porównując rozkład przeżyć testem log-rank. Wyznaczono również percentyle funkcji przeżycia dla grup. Dla wszystkich analiz za poziom istotności statystycznej przyjmowano $a=0,05$.

W wyniku przeprowadzonej procedury przynajmniej jeden węzeł wartowniczy stwierdzono u 131 ze 132 pacjentów (mediana 3, IQR 2-4) - stopień detekcji określono na 99,2\%. Po uwzględnieniu immunohistochemii zgodność metody wyniosła 94,7\% (124/131), czułość określono na 84,4\% (38/45), wskaźnik wyników fałszywie negatywnych wyniósł 15,6\% (7/45). U 4 pacjentów (4/131 - 3,1\%) podczas zabiegu zaobserwowano nietypowy spływ chłonny — wybarwieniu uległy węzły okolicy korzenia krezki. Wartość predykcyjną ujemną określono na 92,5\% (86/93). Zjawisko upstagingu stwierdzone dzięki badaniu immunohistochemicznemu dotyczyło 9,5\% (9/95). W wykreślonych krzywych ROC nie stwierdzono istotnych statystycznie zależności dla wskaźników antropometrycznych wyliczonych na podstawie masy ciała i wzrostu oraz dla cech obserwowanych śródoperacyjnie i makroskopowo w badaniu patologicznym. Statystyczny trend zmniejszenia czułości ( $A \cup C=0,597, p=0,0830$ ) stwierdzono dla krzywej wykreślonej dla stosunku beztłuszczowej masy ciała do masy ciała (z punktem odcięcia na poziomie 0,72). Zestawiając z wynikami głębokość nacieku ściany jelita, stwierdzono statystycznie istotnie gorsze wyniki w zakresie czułości metody dla guzów T3 vs T2 (83\% vs 89\%, p=0,0066). Statystycznie istotnie gorsze wyniki w zakresie zgodności metody uzyskano w przypadkach zajęcia układu chłonnego, nacieku torebki węzła i nacieku tkanki okołowęzłowej (odpowiednio $78 \%$ vs $100 \%, p<0,0001 ; 80 \%$ vs $97 \%, p=0,0023$ oraz $73 \%$ vs 97\%, $p=0,0002$ ). Wykazano również statystycznie istotne różnice $w$ analizie zgodności w zależności od stadium nowotworu: I vs III (100\% vs $81 \%$, $\mathrm{p}=0,0131)$ oraz II vs III (100\% vs $81 \%, \mathrm{p}=0,0004)$.

W analizie przeżyć, porównując grupę chorych bez przerzutów w węzłach z chorymi z mikroprzerzutami oraz z makroprzerzutami, uzyskano statystycznie istotną różnicę ( $p=0,0027)$. Porównując grupę chorych z mikroprzerzutami, nie wykazano istotnych różnic w przeżyciach w bezpośrednim zestawieniu z grupą bez przerzutów w węzłach oraz z grupą $z$ makroprzerzutami (odpowiednio $p=0,6602$ oraz $p=0,1615$ ). W analizie przeżyć grup powstałych po włączeniu chorych z mikroprzerzutami albo do grupy pacjentów wyjściowo bez przerzutów w węzłach chłonnych, albo do grupy z makroprzerzutami, stwierdzono statystycznie istotne różnice (odpowiednio $p=0,0003$ oraz $p=0,0026$ ). W analizie percentyli funkcji przeżycia po włączeniu chorych z mikroprzerzutami do grupy z makroprzerzutami całkowite przeżycie w tej grupie uległo poprawie. Podobne wyniki uzyskano po wyłączeniu grupy pacjentów z rozsiewem choroby na koniec okresu obserwacji. W analizowanym okresie progresji uległo istotnie mniej chorych bez przerzutów w węzłach (3/65) w porównaniu z chorymi ze stwierdzonymi mikroprzerzutami do węzłów wartowniczych (2/6) — różnica ta okazała się statystycznie istotna $(4,62 \%$ vs 33,33\%, $p=0,0084)$.

Na podstawie przeprowadzonych badań sformułowano następujące wnioski: 1) Zachowanie standardów biopsji węzła wartowniczego w raku okrężnicy umożliwia osiągnięcie dobrych wyników w zakresie stopnia detekcji, czułości i zgodności metody oraz uzyskiwanego upstagingu. 2) Wykonanie procedury in-vivo umożliwia zmianę zakresu resekcji przy stwierdzeniu nietypowego spływu chłonnego. 3) Ze względu na wykazany trend zmniejszenia czułości, przy kwalifikowaniu chorych do biopsji węzła wartowniczego w raku okrężnicy przydatne jest określenie stosunku beztłuszczowej masy ciała do całkowitej masy ciała. 4) Czułość procedury w sposób istotny zmniejsza się wraz ze wzrostem głębokości nacieku ściany według TNM. Zgodność jest w statystycznie istotny sposób gorsza dla wyższych stadiów zaawansowania nowotworu według TNM oraz w grupie chorych z przerzutami w węzłach chłonnych, z naciekiem torebki węzła oraz tkanki okołowęzłowej. 5) Grupa chorych 
z mikroprzerzutami nie wykazuje statystycznie istotnej różnicy w przeżyciach ani w porównaniu z chorymi bez przerzutów w węzłach chłonnych, ani w zestawieniu z grupą z makroprzerzutami. Różnica ta widoczna jest przy analizie grup powstałych po włączeniu grupy z mikroprzerzutami albo do grupy bez przerzutów w węzłach, albo do grupy z makroprzerzutami. Włączenie chorych z mikroprzerzutami do grupy z makroprzerzutami poprawia całkowite przeżycia w tej grupie. Chorzy z mikroprzerzutami w węźle wartowniczym statystycznie istotnie częściej ulegają progresji choroby w porównaniu z grupą bez przerzutów w węzłach.

Dr n. med. Piotr Nowaczyk Wielkopolskie Centrum Onkologii w Poznaniu Oddział Chirurgii Onkologicznej i Ogólnej I e-mail:piotr_nowaczyk@o2.pl 